\title{
Physico-Chemical Assessment of the Water Quality of the Yopougon Bay, (Lagune Ebrie, Cote D'ivoire)
}

\author{
Amani Etche Mireille*, Akobe Apie Colette, Assale Fori Paul, Amani Abraham Bledou , Aka \\ Kouamé \\ Département Géologie Marine et Sédimentologie UFR (Unité de Formation et de Recherche) STRM (Sciences \\ de la Terre et des Ressources Minières) Université Félix Houphouët Boigny, Cocody, Abidjan, Côte d'Ivoire.
}

*Corresponding Authors: Amani Etche Mireille, Département Géologie Marine et Sédimentologie UFR (Unité de Formation et de Recherche) STRM (Sciences de la Terre et des Ressources Minières) Université Félix Houphouët Boigny, Cocody, Abidjan, Côte d'Ivoire.

\begin{abstract}
The study focuses on the analysis of the physicochemical parameters of the bay of Yopougon. A first series of data was measured in situ at a fixed station in the bay where a sensor was installed. Another comes from an analysis of the water sample. This work was carried out as part of the monitoring of RNO water (national observation network). Its objective is to evaluate the characteristics of the physico-chemical chemical parameters ( $p H$, temperature, conductivity, TDS, dissolved oxygen, ORP, TSS) of the Yopougon bay and of the nutrient salts (ammonium, nitrite and phosphate).

The study was conducted on the surface and in the bay's water column. The curves obtained show a variation in the physico-chemical parameters from the surface to the depth of the bay.

The concentrations of the parameters are above normal. The waters of Yopougon Bay are warm, alkaline. They are impacted by discharges from agro-industrial companies and wastewater. This water could be very harmful to use and therefore unsuitable for human consumption.
\end{abstract}

Keywords: Bay, physico-chemical parameter, Ebrié lagoon, pollution, Côte d'Ivoire

\section{INTRODUCTION}

Located in West Africa, Côte d'Ivoire has the largest lagoon system in Africa which extends parallel to the shore of the Gulf of Guinea, between $2^{\circ} 50$ 'and $5^{\circ} 25^{\prime}$ West longitude for nearly $300 \mathrm{~km}$ with a total area of $1200 \mathrm{~km} 2$ [1]. This lagoon system is made up of three distinct lagoons from west to east: the Grand-Lahou lagoon, the Ebrié lagoon and the Aby lagoon. The Ebrié lagoon with an area of 532 $\mathrm{km} 2$, develops in the area where physico-chemical, continental and oceanic systems meet. The Ebrié lagoon has many bays [2] which represent nearly a fifth of its surface, or $100 \mathrm{~km} 2$ out of $523 \mathrm{~km} 2$. According to Affian [3] these bays (figure 1) are more frequent on the north shore (Cocody bays, Banco bay, Yopougon bay, Bingerville bay, Adiopo-Doumé bay) than on the south shore (Bays of Bietry, Koumassi, Abou-Abou).

The bay of Yopougon (figure 2), the subject of our study, is located in the southern part of the Ivory Coast, precisely in Abidjan in the commune of Yopougon between the commune of Attécoubé of Yopougon [4]. Located in the city, it is the seat of many activities such as fishing, sand extraction, lagoon transport (canoe, pinasse and ferry), cement factories (incibeton) and plastic waste treatment, navigation, etc. ; hence the interest it arouses.

It receives all dissolved and suspended matter as well as anthropogenic inputs (solid and liquid discharges) which influence the various physicochemical parameters. The bay of Yopougon also receives contributions from the Banco river, the Ebrié lagoon, septic tanks, sewers, wastewater, runoff water, etc.

As part of the activities of the national observation network (RNO) in Côte d'Ivoire, campaigns to measure the physico-chemical parameters of the bay $(\mathrm{pH}$, temperature, conductivity, TDS (total dissolved solid), dissolved oxygen, ORP (oxidation-reduction potential), TSS (Total Suspended solid), 
etc.) of the waters of Yopougon bay and analyzes of the samples from these waters were carried out in order to find the nutrient content. This water monitoring will make it possible to know the quality of the water in this environment by determining its physico-chemical parameters.

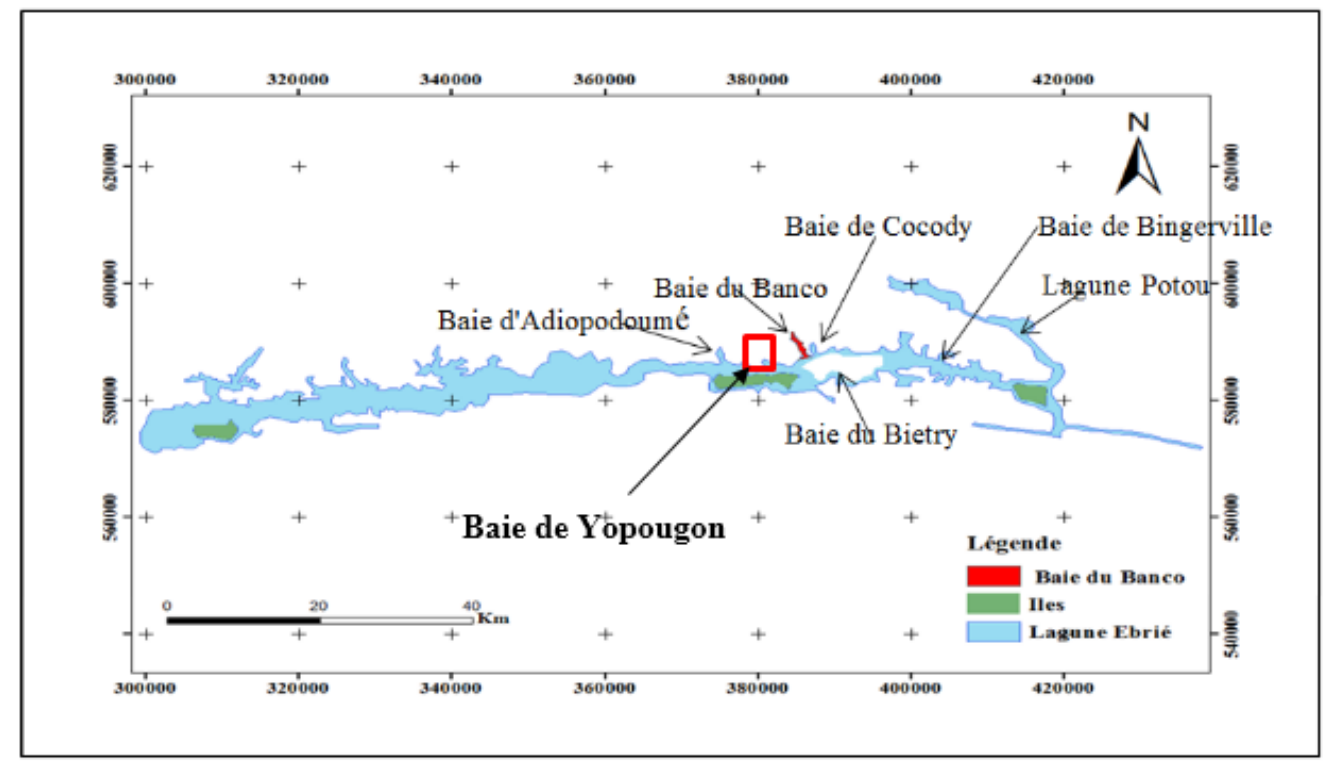

Figure1. Ebrie lagoon Système [5]

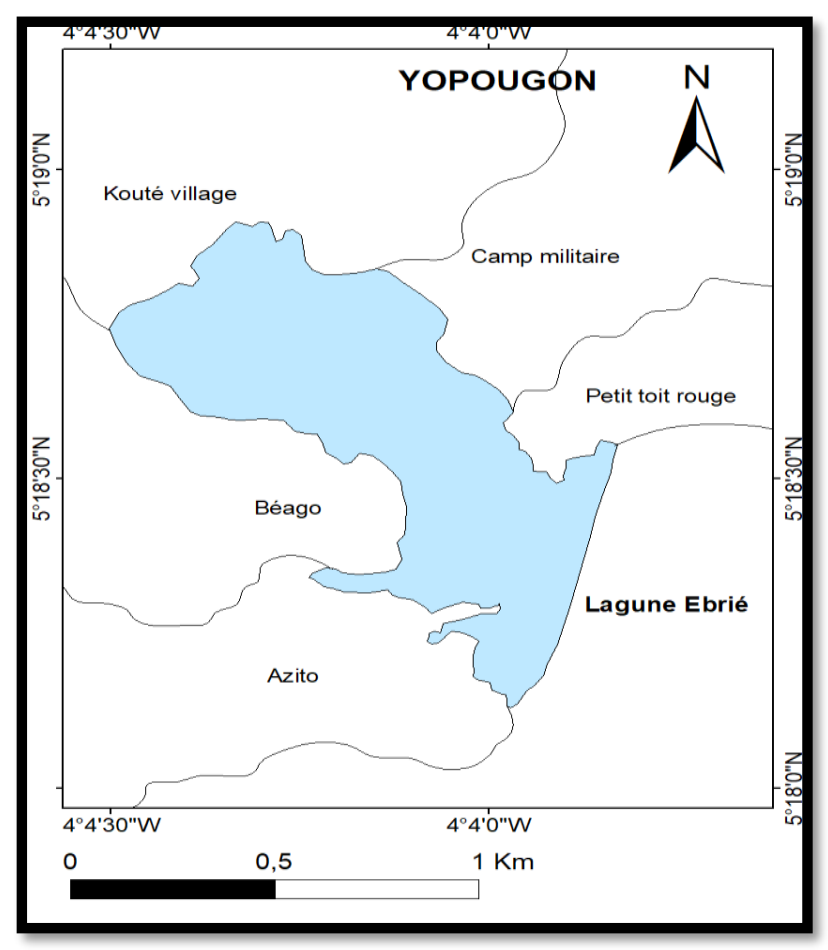

Figure2. Yopougon's bay

\section{MATERIAL AND MethodS}

\subsection{Physico-Chemical Data Acquisition Equipment}

The equipment used for this study includes field devices, laboratory equipment and computer programs. These materials made it possible to carry out research work while collecting data and samples.

Field equipment:

-A speedboat that was used as a means of transport over the expanse of Banco and Yopougon bays in order to take samples.

-A GPS to record the coordinates of each of the different sampling stations. 
- A 6920 V2 (YSI) brand multi-parameter. It made it possible to measure the values of the physicochemical parameters of the Banco and Yopougon bays. The physico-chemical data are read on the screen of a multi-parameter probe.

-A bottle of Niskin which was used to take samples of water from the depths

\section{Computer Program for Processing Physico-Chemical Data.}

- Excel software

This software allowed the creation of the database of physicochemical parameters and the realization of the different curves to evaluate the different parameters.

\subsection{Methodology}

\subsubsection{Processing of Physico-Chemical Data}

Obtaining data will be done in two ways:

Initially, the physicochemical parameter measurements ( $\mathrm{pH}$, temperature, conductivity, TDS, dissolved oxygen, ORP, TSS, etc.) will be carried out in situ with a sensor placed at a station in the bay.

Then water samples will be taken in sterilized containers and transferred to the laboratory. These Samples Will Be Analyzed For The Nutrient Content ((Nitrite, Nitrate, Ammonium, Phosphate) ...

\subsubsection{Realization of the Curves of the Physico-Chemical Parameters}

The variation curves of the physicochemical parameters were produced using Excel software. The establishment of the curves consists in creating graphic files from the data files of the physico-chemical parameters during the water samples at the different stations $(\mathrm{pH}$, temperature, conductivity, TDS, dissolved oxygen, ORP, TSS, etc.) arranged in rows. Column using Excel spreadsheet.

\subsubsection{Evaluation of Gradients at the Level of the Various Parameters}

After having established the different curves of each physicochemical and organic parameter, the gradients were determined in each parameter. The gradient for each parameter was determined according to the following standard:

The bottom value of the parameter in question minus the value of this parameter at the surface, the result obtained is divided by the difference of the distance between the bottom and the surface.

\section{RESULT AND DISCUSSION}

\subsection{Physico-Chemical of the Water Column in the Bay of Yopougon}

Table 1 presents the values of the physico-chemical parameters of the bay of Yopougon measured in the field.

Table1. Values of the physico-chemical parameters of the bay of Yopougon

\begin{tabular}{|l|l|l|l|l|l|l|l|l|}
\hline $\begin{array}{l}\text { Water } \\
\text { level }\end{array}$ & $\begin{array}{l}\text { outline } \\
(\mathrm{m})\end{array}$ & $\mathbf{T}^{\circ} \mathbf{C}$ & $\mathbf{p H}$ & $\mathbf{O}_{2}(\mathrm{mg} / \mathrm{L})$ & Cond. $(\mu \mathrm{S} / \mathrm{cm})$ & $\begin{array}{l}\text { Salinity } \\
(\% \mathrm{o})\end{array}$ & $\begin{array}{l}\text { TSS } \\
(\mathbf{g} / \mathbf{L})\end{array}$ & $\mathbf{O R P}(\mathrm{mV})$ \\
\hline Surface & 0,5 & 27,97 & 6,88 & 4,98 & 6074 & 3,10 & 3,74 & 636 \\
\hline depth & 3,2 & 27,01 & 6,38 & 0,63 & 8583 & 4,58 & 5,36 & 644 \\
\hline
\end{tabular}

\subsection{Analyzes of the Physico-Chemical Parameters of the Bay of Yopougon}

- Temperature

The temperature of Yopougon bay varies from $27.01^{\circ} \mathrm{C}$ to $27.97^{\circ} \mathrm{C}$ with an average of $27.49^{\circ} \mathrm{C}$ (Table I). It decreases from the surface to the bottom (figure 3). There is a temperature variation of $0.96{ }^{\circ} \mathrm{C}$ between surface and depth with a thermal gradient of $0.35^{\circ} \mathrm{C} / \mathrm{m}$.

Table 1. Values of the physico-chemical parameters of the bay of Yopougon

\begin{tabular}{|l|l|l|l|l|l|l|l|l|}
\hline $\begin{array}{l}\text { Water } \\
\text { level }\end{array}$ & $\begin{array}{l}\text { outline } \\
(\mathrm{m})\end{array}$ & $\mathbf{T}^{\circ} \mathbf{C}$ & $\mathbf{p H}$ & $\mathbf{O}_{2}(\mathrm{mg} / \mathrm{L})$ & Cond. $(\mu \mathrm{S} / \mathrm{cm})$ & $\begin{array}{l}\text { Salinity } \\
(\%)\end{array}$ & $\begin{array}{l}\text { TSS } \\
(\mathbf{g} / \mathbf{L})\end{array}$ & $\mathbf{O R P}(\mathrm{mV})$ \\
\hline Surface & 0,5 & 27,97 & 6,88 & 4,98 & 6074 & 3,10 & 3,74 & 636 \\
\hline depth & 3,2 & 27,01 & 6,38 & 0,63 & 8583 & 4,58 & 5,36 & 644 \\
\hline
\end{tabular}

\subsection{Analyzes of the Physico-Chemical Parameters of the Bay of Yopougon}

\subsubsection{Temperature}

The temperature of Yopougon bay varies from $27.01^{\circ} \mathrm{C}$ to $27.97^{\circ} \mathrm{C}$ with an average of $27.49^{\circ} \mathrm{C}$ (Table I). It decreases from the surface to the bottom (figure 3). There is a temperature variation of $0.96{ }^{\circ} \mathrm{C}$ between surface and depth with a thermal gradient of $0.35^{\circ} \mathrm{C} / \mathrm{m}$. 


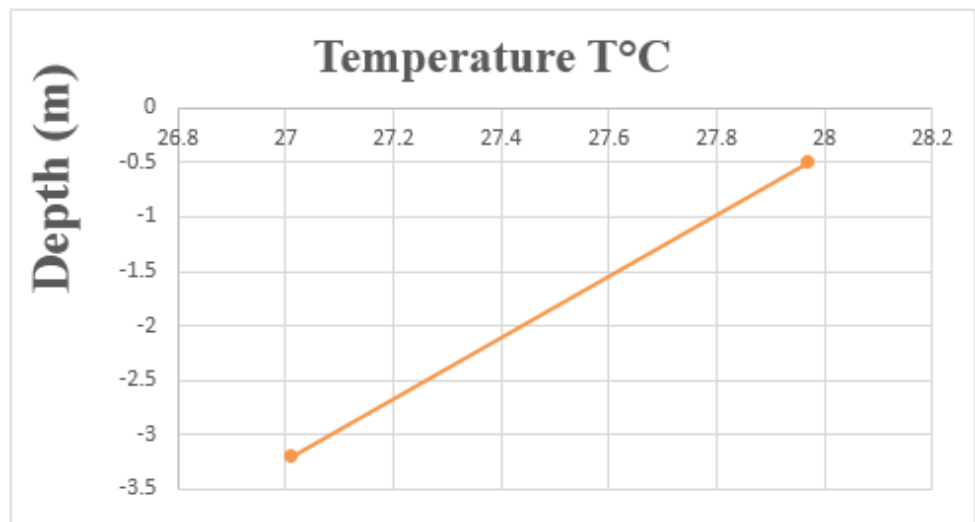

Figure3. Temperature evolution in Yopougon bay

\subsection{2. $\mathrm{pH}$}

The $\mathrm{pH}$ of Yopougon Bay is between 6.38 to 6.88 with an average of 6.63 (Table 1). It decreases from the surface to the bottom (figure 4). There is a $\mathrm{pH}$ variation of 0.5 between surface and depth with an acidity potential of $0.18 . \mathrm{m}-1$

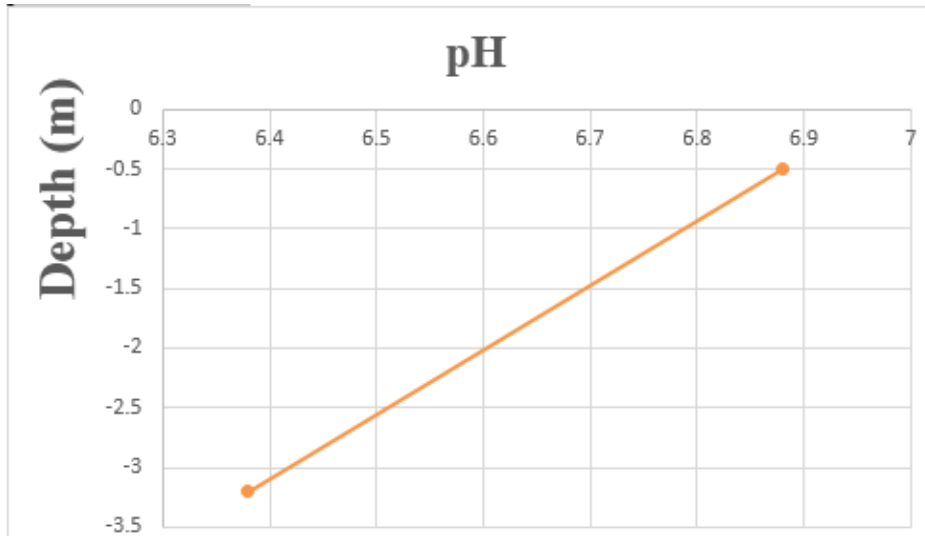

Figure4. Evolution of the $p H$ in the bay of Yopougon

\subsubsection{Electrical conductivity}

The electrical conductivity of Yopougon bay ranges from 6074 to $8583 \mu \mathrm{S} / \mathrm{cm}$ with an average of $7328.5 \mu \mathrm{S} / \mathrm{cm}$ (Table I). There is a high level of electrical conductivity in the depth of the bay (8583 $\mu \mathrm{S} / \mathrm{cm}$ ) (figure 5). The electrical conductivity increases from the surface to the bottom with a rate of $2509 \mu \mathrm{S} / \mathrm{cm}$ and a conductivity gradient of $929.25 \mu \mathrm{S} / \mathrm{cm} . \mathrm{m}-1$.

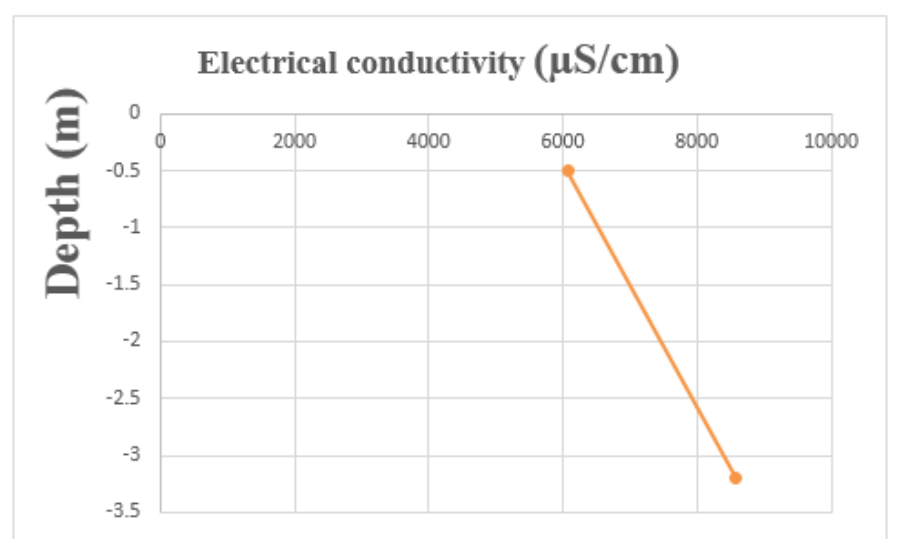

Figure5. Evolution of electrical conductivity in the bay of Yopougon

\subsubsection{Salinity}

The salinity in the bay of Yopougon is 3.1 to $4.58 \%$ o with an average of $3.84 \%$ o (Table I). There is a variation in salinity of 1.48 from the surface to the bottom with $0.55 \%$ o.m-1. Salinity increases from 
surface to depth (Figure 6). The level of salinity is more concentrated at the depth of the bay $(4.58 \% \mathrm{o})$ than at the surface $(3.1 \%$ o).

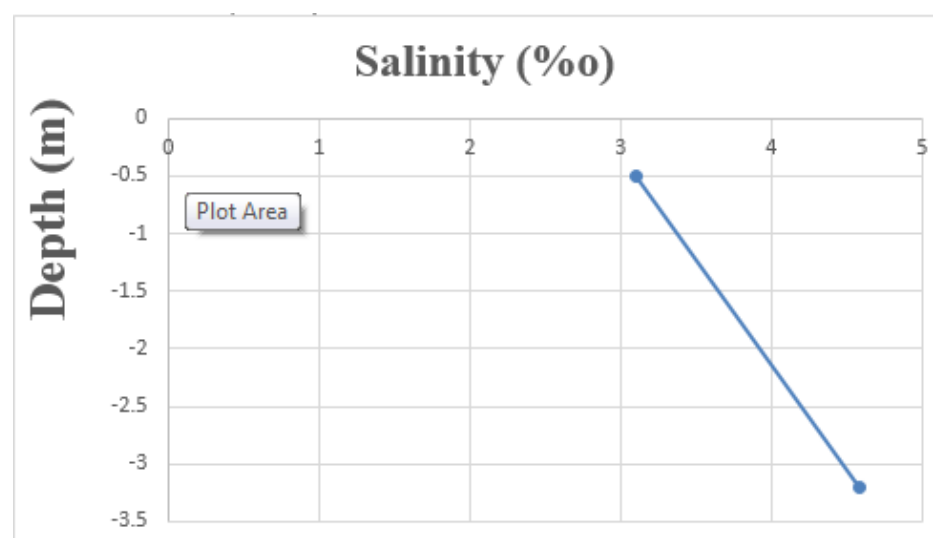

Figure6. Evolution of salinity in Yopougon bay

\subsubsection{Dissolved oxygen}

The dissolved oxygen level in Yopougon bay varies from 0.63 to $4.98 \mathrm{mg} / \mathrm{L}$ with an average of 2.80 $\mathrm{mg} / \mathrm{L}$ (Table I). At the surface, dissolved oxygen is higher at the surface in the bay $(4.98 \mathrm{mg} / \mathrm{L}$ ) than at depth $(0.63 \mathrm{mg} / \mathrm{L})$. The dissolved oxygen level decreases from the surface to the bottom (Figure 7) with an oxygen gradient of $1.61 \mathrm{mg} / \mathrm{L} . \mathrm{m}-1$. There is therefore a variation in the dissolved oxygen level of $4.35 \mathrm{mg} / \mathrm{L}$.

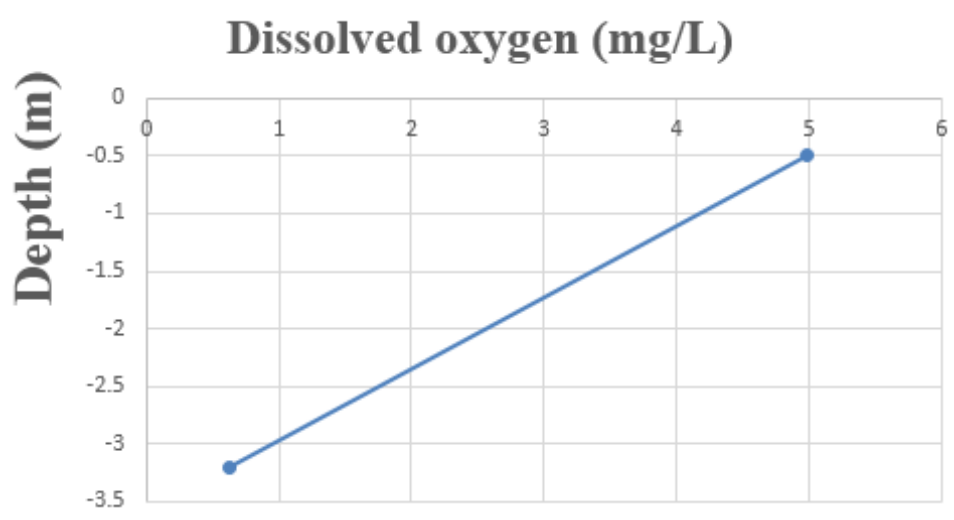

Figure7. Evolution of dissolved oxygen in Yopougon bay

\subsubsection{Redox potential (ORP)}

The variation of the redox potential in the bay of Yopougon is between 636 to $644 \mathrm{mV}$ with an average of $640 \mathrm{mV}$ (Table I). The redox potential increases from the surface $(636 \mathrm{mV})$ to the depth $(644 \mathrm{mV})$ (Figure 8). There is therefore a variation of the redox potential of $8 \mathrm{mV}$ from the surface to the bottom with an redox gradient of $2.96 \mathrm{mV} . \mathrm{m}-1$.

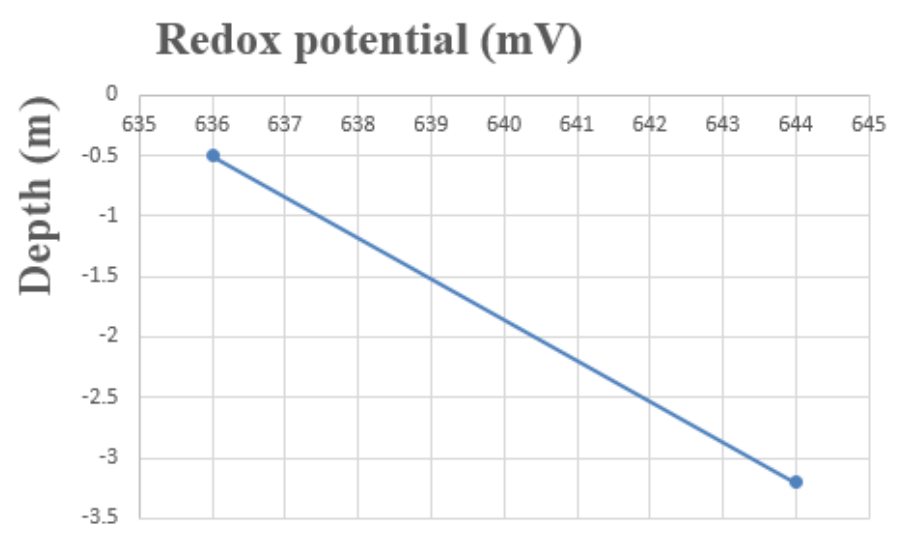

Figure8. Evolution of dissolved oxygen in Yopougon bay 


\subsubsection{Total Dissolved Solids (TDS)}

The rate of total dissolved solid (TDS) in the bay of Yopougon is 3.74 to $5.36 \mathrm{~g} / \mathrm{L}$ with an average of $4.55 \mathrm{~g} / \mathrm{L}$ (Table 1). There is an increase in the rate of total dissolved solids from the surface to the bottom (Figure 9). Water contains more of the total dissolved solid at depth than at the surface. There is a rate of change in total dissolved solid of $1.62 \mathrm{~g} / \mathrm{L}$ with a dissolved solid gradient of $0.6 \mathrm{~g} / \mathrm{L} . \mathrm{m}-1$.

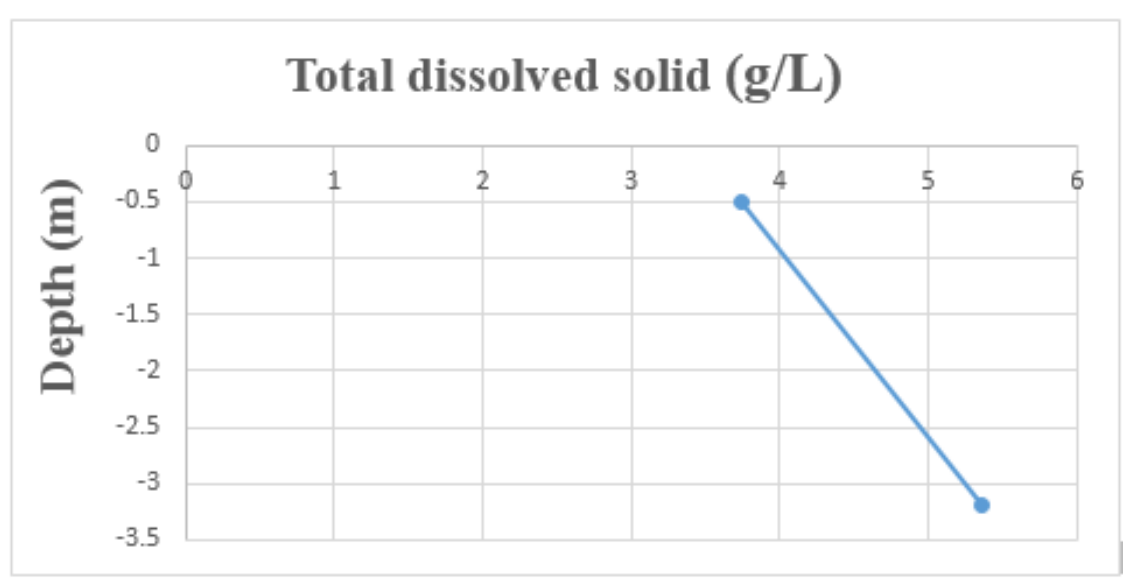

Figure9. Evolution of the total dissolved solid in the bay of Yopougon

\subsection{Analyzes of organic parameters in Yopougon Bay}

Table 2 presents the values of the organic parameters of the bay of Yopougon.

Table 2. Values of organic parameters in Yopougon Bay

\begin{tabular}{|l|l|l|l|l|l|}
\hline Water level & $\mathbf{N O}_{3}{ }^{-}(\mathrm{mg} / \mathrm{L})$ & $\mathbf{N O}^{-}(\mathrm{mg} / \mathrm{L})$ & $\mathbf{N H}_{4}{ }^{+}(\mathrm{mg} / \mathrm{L})$ & $\mathbf{P O}_{4}{ }^{3-}(\mathrm{mg} / \mathrm{L})$ & $\mathbf{M E S}(\mathrm{mg} / \mathrm{L})$ \\
\hline Surface $(0,5 \mathrm{~m})$ & 0,1 & 0,048 & 3,0 & 0,65 & 20 \\
\hline depth $(3,2 \mathrm{~m})$ & 0,1 & 0,041 & 0,8 & 0,54 & 20 \\
\hline
\end{tabular}

\subsubsection{Total Suspended solid (TSS)}

The Total Suspended solid in the bay of Yopougon oscillates around $20 \mathrm{mg} / \mathrm{L}$ with an average of 20 $\mathrm{mg} / \mathrm{L}$ (Table 2). There is no variation in Total Suspended solid from the surface to the bottom (Figure 10) and therefore the potential for turbidity is $0 \mathrm{mg} . \mathrm{L}-1 / \mathrm{m}$. There is therefore a homogeneity of the Total Suspended solid from the surface to the depth.

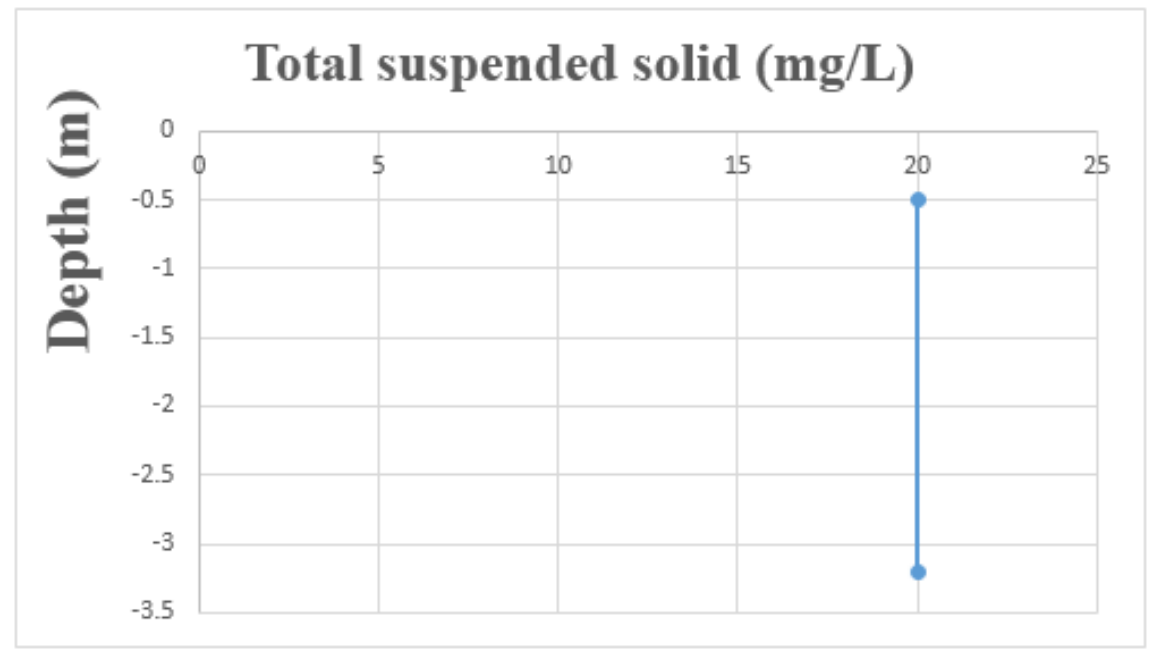

Figure10. Evolution of Total Suspended solid in the bay of Yopougon

\subsubsection{Phosphate (PO43-)}

The variation in phosphate in Yopougon Bay is 0.54 to $0.65 \mathrm{mg} / \mathrm{L}$ with an average of $0.59 \mathrm{mg} / \mathrm{L}$ (table 2). The phosphate level decreases from the surface $(0.65 \mathrm{mg} / \mathrm{L})$ to the bottom $(0.54 \mathrm{mg} / \mathrm{L})$ (figure 11). The variation in the phosphate level is $0.11 \mathrm{mg} / \mathrm{L}$ and with a phosphate gradient of 0.04 $\mathrm{mg} / \mathrm{L} . \mathrm{m}-1$. 


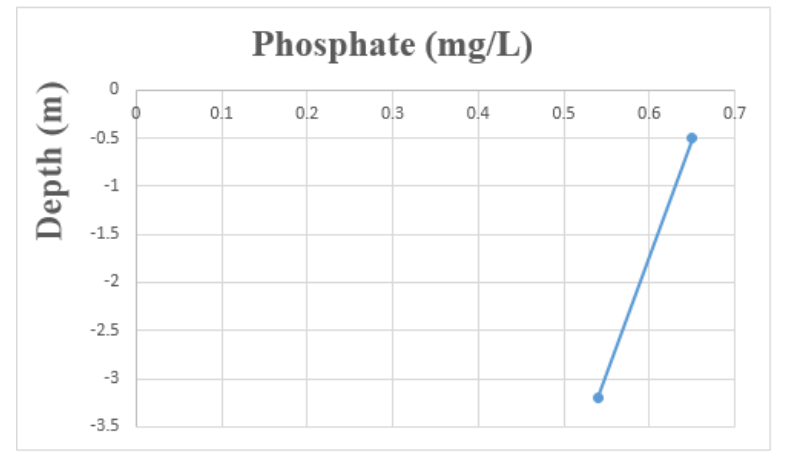

Figure11. Evolution of phosphate in the bay of Yopougon

\subsubsection{Nitrite (NO2-)}

Nitrite in the bay of Yopougon varies from 0.041 to $0.048 \mathrm{mg} / \mathrm{L}$ with an average of $0.045 \mathrm{mg} / \mathrm{L}$ (Table II). There is a variation of the nitrite level of $0.007 \mathrm{mg} / \mathrm{L}$ with a nitrite gradient of $0.002 \mathrm{mg} /$ L.m-1. The nitrite level decreases from the surface to the bottom (figure 12).

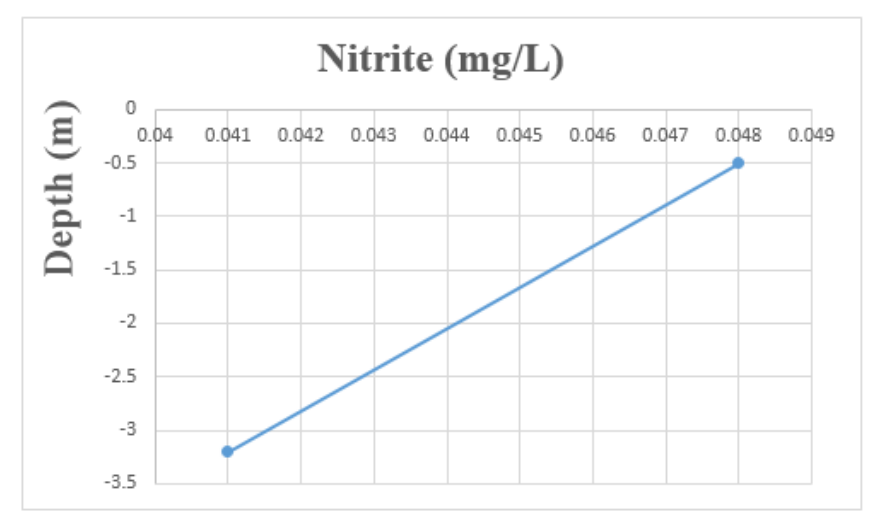

Figure12. Evolution of nitrite in the bay of Yopougon

\subsubsection{Nitrate (NO3-)}

The nitrate level in Yopougon bay remains constant at $0.1 \mathrm{mg} / \mathrm{L}$ and does not vary with depth with an average of $0.1 \mathrm{mg} / \mathrm{L}$ (Table 2). The same rate observed at the surface is observed at depth (figure 13). There is therefore a homogeneity of the nitrate from the surface to the bottom. So we have a nitrate gradient of $0 \mathrm{mg} / \mathrm{L} . \mathrm{m}-1$.

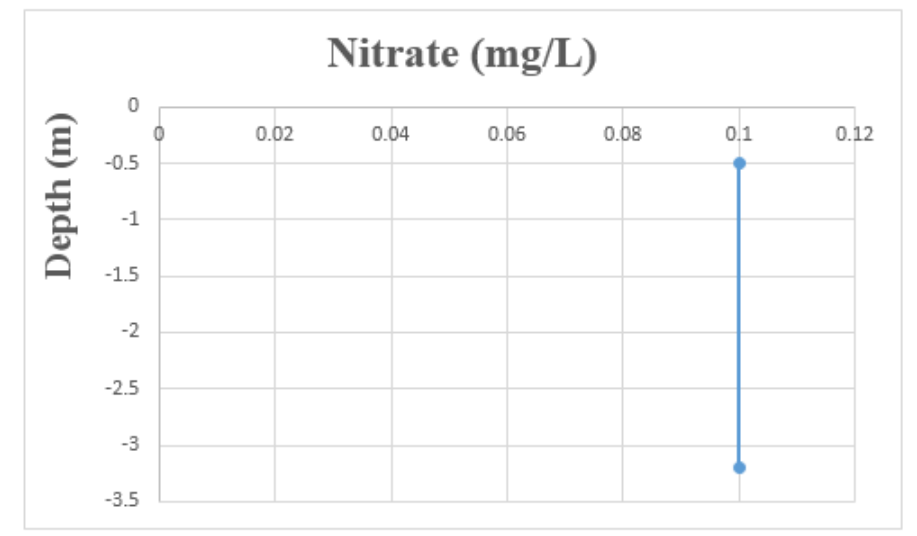

Figure13. Evolution of nitrate in the bay of Yopougon

\subsubsection{Ammonium $(\mathrm{NH} 4+)$}

There is a variation in ammonium from 0.8 to $3 \mathrm{mg} / \mathrm{L}$ with an average of $1.9 \mathrm{mg} / \mathrm{L}$ (Table II). The ammonium level observed at the surface of the bay $(3 \mathrm{mg} / \mathrm{L})$ is greater than the ammonium level observed in the depth of the bay $(0.8 \mathrm{mg} / \mathrm{L})$, the variation in the ammonium level is $2,2 \mathrm{mg} / \mathrm{L}$ with an ammonium gradient of $0.81 \mathrm{mg} / \mathrm{Lm}-1$. Ammonium decays from the surface to the bottom (Figure 14). 


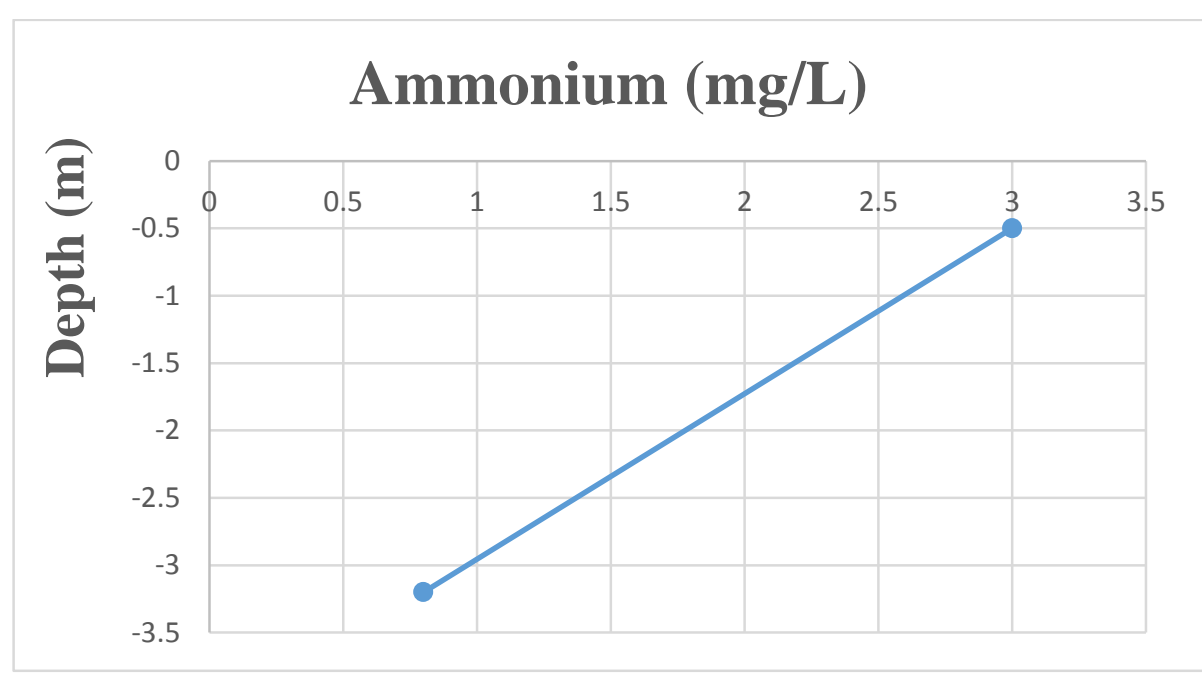

Figure14. Evolution of ammonium in the bay of Yopougon

\section{Interpretation of the Physico-Chemical Parameters of Yopougon Bay}

\section{-Temperature}

The water temperatures in Yopougon Bay vary depending on the depth. At the surface, the water temperature is high compared to the water temperature at depth. This is because the surface receives direct sunlight. These help heat water on the surface to a depth of $0.5 \mathrm{~m}$ faster than water at a depth of $3.2 \mathrm{~m}$. In addition to this, the high turbidity of the water prevents the penetration of light rays deep into the bay. The water in the bay at the surface has a temperature of $27.97^{\circ} \mathrm{C}$ and that of the depth at 27.01

${ }^{\circ} \mathrm{C}$. These values are higher than the WHO standard [6] for which water intended for drinking should have a temperature below $22^{\circ} \mathrm{C}$.

Temperature increases the rates of chemical and biochemical reactions. The change in the temperature of a watercourse remains linked to local conditions such as regional climate, topography, duration of sunshine, flow and depth [7]. According to Aka [8], water is poor when the temperature is between 25 ${ }^{\circ} \mathrm{C}$ and $30^{\circ} \mathrm{C}$. The water in Yopougon Bay is poor water.

- $\mathbf{p H}$

The $\mathrm{pH}$ of Yopougon bay varies on average around 6.63 ranging from 6.38 to 6.88 . The berry has a $\mathrm{pH}$ that has a substantially neutral average (6.63). The $\mathrm{pH}$ of the bay depends on the continental and oceanic inputs [9]. The neutrality of the $\mathrm{pH}$ could be due to the presence of bicarbonate which helps to buffer the flowing water. The decrease in $\mathrm{pH}$ from the surface to the depth is due to the contact of the lagoon with the bay. This parameter characterizes a large number of physico-chemical equilibria and depends on multiple factors, including the origin of the water [10]. It also depends on the geological nature of the environment crossed, on the discharge of wastewater [11]. In general, an increase in the $\mathrm{pH}$ causes the precipitation of metal cations as insoluble metal hydroxides or oxides. $\mathrm{PH}$ also plays an essential role in the adsorption of metals to organic matter. If the $\mathrm{pH}$ oscillates between 4.5 and 10: it has no effect on the quality of the water and therefore living species are not affected. If it is not in this range, it becomes harmful to living things [12].

\section{-Electrical conductivity}

The average value of the electrical conductivity at the Yopougon bay is 7328.5 with a variation which increases from the surface to the depth $(6074$ to $8583 \mu \mathrm{S} / \mathrm{cm})$.

Very poor water quality is observed when the value is greater than $3000 \mu \mathrm{S} / \mathrm{cm}$ [13]. Conductivity is influenced by various natural and anthropogenic factors. The conductivity of natural water is between 50 and $1500 \mu \mathrm{S} / \mathrm{cm}$ [14]. The water in Yopougon Bay is of poor quality.

\section{- Salinity}

The mean value of salinity at the Yopougon bay has an average of 3.84 de with a variation from the surface towards the depth of 3.1 to $4.58 \%$. The variation in salinity at these different depths of Yopougon Bay can also be explained by poor hydrodynamics, the effect of the tides is weak. 


\section{- Dissolved oxygen}

Yopougon bay also has a dissolved oxygen value ranging from the surface to depth (4.98 to $0.63 \mathrm{mg} /$ $\mathrm{L}$ ) with an average of $2.80 \mathrm{mg} / \mathrm{L}$. These low concentrations in the bays are explained by the fact that the bay of Yopougon is fed by water from surrounding factories, wastewater and runoff. All this water laden with suspended matter contributes to the reduction of dissolved oxygen in the bay.

The concentration of dissolved oxygen in a lagoon varies depending on the organic matter, water temperature, depth, time of day, and nutrients in the lagoon. Sensitive fish species can be disturbed by an oxygen content of less than $4 \mathrm{mg} / 1$ [14].

\section{- Oxidation-reduction potential or ORP}

The oxidation-reduction potential (ORP) of the bay of Yopougon has an average of $640 \mathrm{mV}$. The cutoff value for the redox potential is $616.8 \mathrm{mV}$. This value makes it possible to judge the sanitation process of the bay of Yopougon, because it promotes good oxygenation of the waters of the bays. Thus, the sanitation process in Yopougon Bay does not promote good oxygenation.

\section{- Total Dissolved Solids (TDS)}

Yopougon bay has an average TDS rate of $4.55 \mathrm{~g} / 1$. These high concentrations of TDS in the bay of Yopougon promote the decomposition of organic matter brought in by runoff. Compared to the threshold value which is $1 \mathrm{~g} / \mathrm{L}$, we can say that the waters of Yopougon bay are polluted and contain dissolved solids in abundance.

Unlike organic pollutants, metals cannot be degraded biologically or chemically. There is no fixed guideline value but the optimum is below 1000mg / 1 [14].

\section{- Total Suspended solid}

The bay of Yopougon has an average suspended matter content of $20 \mathrm{mg} / \mathrm{L}$. The water in this bay is loaded with Total Suspended solid, which reduces transparency and therefore photosynthesis which reduces the amount of fish present in the water.

When the oxygen concentrations decrease, the medium becomes more reducing which results in a reduction of the redox potential. In natural waters, relative comparisons of the evolution of the redox potential can be useful to follow the degrees of change of the aquatic system [14]. The concentrations recorded at different levels of the bay are explained by urbanization and the industrialization by supplying a large quantity of domestic wastewater on the one hand, and on the other hand by solid waste.

\section{- Phosphate (PO43-)}

Yopougon bay has an average rate of $0.59 \mathrm{mg} / \mathrm{L}$. This value is above the threshold value which is 0.5 $\mathrm{mg} / \mathrm{L}$. This justifies that the quality of the water in Yopougon Bay is not of good quality. This berry therefore presents a danger for photosynthetic organisms (micro-algae).

- Nutritional salts

Nutrient salts show high average values compared to cutoff values. These high average values reflect a high content of nutrient salts in the bay of Yopougon. This high content is linked to accelerated urbanization, the growing use of fertilizers, demographic and industrial growth in the bay, and domestic wastewater.

\section{CONCLUSION}

The analysis of the physicochemical parameters made it possible to know the variation in the content of the different parameters in the water column of the bay of Yopougon. In general, the waters of Yopougon Bay are warm, neutral and less oxygenated.

At depth, the electrical conductivity, salinity, redox potential, total dissolved solids and suspended solids have high values which are due to inputs from lagoon and continental waters.

The depth of Yopougon bay benefits from an oxygenation process according to the values of the redox potential 
Temperature, $\mathrm{pH}$, dissolved oxygen and nutrient salts are equally abundant on the surface of the water. The bay is teeming with a large amount of suspended matter and solid waste. The threshold value of the total dissolved solid indicates that the bay of Yopougon is polluted.

The average values obtained for the various physicochemical parameters compared to the standards of drinkability for drinking water indicated by the World Health Organization (WHO, 2004) allow to say that the water of the bay of Yopougon is unfit for consumption. .

As a result, it requires prior, comprehensive and specialized treatment before consumption.

The degradation of water quality is caused by the many external inputs (runoff water, wastewater, etc.).

\section{REFERENCES}

[1] Akpo K. S., Ouattara M. J. P., Eba G. M., Ouffouet S., Coulibaly L., Etat de la pollution fécale dans les baies de la lagune Ebrié (Banco, Cocody et M'Badon) à Abidjan, Côte d'Ivoire. J. Mater. Environ. Sci. 7 (2) 621 630 (2016).

[2] Varlet F., Le régime de la lagune Ebrié (Côte d'Ivoire). Paris. Trav. Doc. Orstom, 83 p (1978).

[3] AFFIAN K., Approche environnementale d'un écosystème lagunaire microtidal (Lagune Ebrié en Côte d'Ivoire), par des études géochimiques et hydrologiques, bathymétriques et hydrologiques : Cotribution du S.I.G. et de la télédétection, Thèse Doctorat, Université Cocody, 225p (2003).

[4] Amani A., Evaluation de la qualité des eaux des baies du banco et de Yopougon (lagune Ebrié, Côte d'Ivoire). Master, Univ Félix Houphouët Boigny, 68p (2019).

[5] Odjohou A., Caractérisation morphologique et hydrologique de la baie estuarienne du banco : lagune Ebrié (Côte d'Ivoire). Mém. DEA, Univ. Cocody, Côte d'Ivoire, 106p (2015).

[6] OMS, Guidelines for drinking water quality, volume 1, recommendations. First addendum to 3 rd edn. World Health Organization (WHO), Genève, Suisse, 595 p (2006)..

[7] Mc Neely J., Miller K. , Reid W., Werner T., Conservation de la diversité biologique mondiale. Union internationale pour la conservation de la nature et des ressources naturelles. Institut des ressources mondiales, conservation international, WWF-US et banque mondiale, Washington, DC, (1990).

[8] Aka A. , Wognin A., Amani E. , Irie Bi. T. , Coulibaly A. , Monde S., Analyse des paramètres physicochimiques et bactériologiques des eaux de l'estuaire de la lagune Ebrié (Sud-Est de la Cote D'Ivoire). European Journal of Scientific Research Vol. 147 No 3, pp. 301-314 (2017).

[9] Keumean N. , Hydrogéochimie des métaux lourds et fonctionnement d'un grau dans le golfe de Guinée: cas de l'embouchure du fleuve Comoé à Grand-Bassam (sud-est de la cote d'ivoire).These de doctorat. Universite Felix Houphouet Boigny, 201p (2013).

[10] Yapo O., Contribution à l'évaluation de l'état de trophie du lac de Buyo (Sudouest de la Côte d'Ivoire): Etude analytique et statistique des paramètres physico-chimiques et biologiques, Thèse unique de doctorat en sciences et Gestion de l'Environnement, (2002).

[11] El Morhit M., Hydrochimie, éléments traces métalliques et incidences Ecotoxicologiques sur les différentes composantes d'un écosystème estuarien (Bas Loukkos). Thèse Doctorat ès science, Université Mohammed V Agdal, Rabat. IMIST. Series/Report No Th571.95/MOR : 33 p (2009).

[12] Ekponon K. , Analyse des paramètres hydrologiques de la baie estuarienne de Bietri : lagune Ebrié (côte d'ivoire). Mém. Master, Université Felix Houphouët Boigny, 65p (2018).

[13] SEQ-EAU, Système d'Evaluation de la qualité de l'eau des cours d'eau Grille d'évaluation SEQ-Eau. MEDD ET Agence de l'eau, $40 \mathrm{p}$ (2009).

[14] J. De Villers, M. Squilbin, C. Yourassowsky, Qualité physico-chimique et chimique des eaux de surface: cadre général. Fiche 2, 158-162, (2005).

Citation: Amani Etche Mireille, et.al., " Physico-Chemical Assessment of the Water Quality of the Yopougon Bay, (Lagune Ebrie, Cote D'ivoire)", International Journal of Research in Environmental Science (IJRES), vol. 6, no. 4, pp. 41-50, 2020. Available: DOI: http://dx.doi.org/10.20431 /2454-9444.0604004

Copyright: (ㅇ 2020 Authors. This is an open-access article distributed under the terms of the Creative Commons Attribution License, which permits unrestricted use, distribution, and reproduction in any medium, provided the original author and source are credited. 